\title{
Explaining History of eGovernment Implementation in Developing Countries: An Analytical Framework
}

\author{
Fathul Wahid \\ Department of Information Systems, University of Agder, Kristiansand, Norway \\ Department of Informatics, Universitas Islam Indonesia, Yogyakarta, Indonesia \\ fathul.wahid@uia.no
}

\begin{abstract}
The paper proposes an analytical framework to explain history of eGovernment implementation over a certain period of time in the context of developing countries. The framework is built upon General Systems Theory (GST) and Institutional Theory enriched with literature from organizational changes, and information systems/e-Government implementation. Three scenarios of implementation are proposed, each with its own departing worldview (i.e., mechanistic, organic, and colonial systems), isomorphic mechanism, implementation model, and possible impact.
\end{abstract}

Keywords: General Systems Theory, Institutional Theory, mechanistic systems, organic systems, colonial systems, e-Government, developing countries.

\section{Introduction}

Countries in the world have been investing a lot of resources in implementing eGovernment in various levels and aspects. While some governments have been successful in implementing e-Government initiatives, many initiatives fail to live up to expectations [16]. In general, development of e-Government in developing countries is lagging behind developed countries [54]. As noted by Sein [44], "implementing eGovernment initiatives in developing countries is a complex and challenging process that face many hurdles."

Having this in mind, backdrop of this paper is twofold. Firstly, hitherto, most of the existing models of e-Government evolution suggest a natural linear progression [29]. This linear progression is indicated in various stage models that could be found in the literature [27, 30, 39, 46]. As noted by Lyytinen and Newman [28], "a majority of change studies treat the change as a simple, linier progression where a new (technical) system is designed, adopted, and modified in step-wise manner." Due to the absent of considering contextual specificity, this linear progression model has been criticized and extended [1, 29, 30].

In order to make e-Government implementation relevant for a specific context, serious consideration must be given to the social, cultural, and economic differences in e-Government development [5, 29]. Moon [30] points out that the stage model is a conceptual tool to examine the evolution of e-Government, and in practice, it may not follow a true linear progression. Coping with the limitations of the linear progression model, for instance, Lyytinen and Newman [28] develop a punctuated socio-technical 
change model which is based upon socio-technical theory viewing organizational systems as multivariate systems of four interacting and aligned components, i.e., task, structure, actor, and technology.

Secondly, in connection to this issue, in a literature review, Walsham and Sahay [58] identify several limitations in IS research in developing countries. The limitations include lack of in-depth study on IS implementation in developing countries. They also call for more action research and longitudinal study. Similarly, Yildiz [59], Heeks and Bailur [17], and Stanforth [50] suggest e-Government researchers to pay more attention on process-oriented or longitudinal studies, beyond output-based or factorial or cross-sectional studies that have been being focus of the e-Government studies in the last decade. To our knowledge, only a few studies in e-Government employ a longitudinal analysis. Among the exceptions include the studies by Pan et al. [36], Stanforth [49], and Heeks and Stanforth [18].

Against these backdrops, the current paper can be considered as a first attempt to address the call and fulfil the mentioned void by proposing an analytical framework built upon General Systems Theory (GST) along with Institutional Theory to explain development of e-Government over certain period of time. GST enables holistic study of history and allows multiple, simultaneous paradigms, each with its own system metaphors [38]. Three system metaphors, e.g., mechanistic, organic, and colonial systems will act as historical-construct inventories [38]. In addition, Institutional Theory, which might be used as a lens to study history of IS implementation within an organization [3], is brought in to explain how collective awareness or isomorphic change occurs. Institutional Theory offers three mechanisms of institutional isomorphic change: coercive, mimetic, and normative [9, 42]. Explanation using these two theories is hoped to provide a fresh interpretation how e-Government initiatives evolve over a certain period of time, which in many cases cannot be explained by the extant e-Government linear progression models.

Following this introduction, the rest of the paper is organized as follows. Section 2 and 3 respectively explains the main conceptions of GST and Institutional Theory. Next, Section 4 explicates and integrates these two theories along with literature from organizational change and e-Government implementation as an analytical framework to explain e-Government implementation. Lastly, Section 5 draws concluding remarks that bring this paper to end.

\section{General Systems Theory}

Ludwig von Bertalanffy and Kenneth Boulding are among the most prominent founders of GST [47]. The GST thinking is based on the fact that after examining laws in various fields of science (e.g. biology, physics, medicine, psychology, social sciences), von Bertalanffy [56] found what he calls formally identical or isomorphic laws. Isomorphism exists "when common characteristics, structures, formulas, and forms of organization are in accordance in different systems" [47:39]. Various forms of GST can be found in literature [47]; for example, Miller's Living Systems Theory [11, 47], Checkland's System Typology [8, 47] and Porra et al.'s [38] three metaphors, i.e. mechanistic, organic, and colonial systems. As aforementioned, this paper will adopt the three metaphors proposed by Porra et al. [38]. Each of the metaphors is explained in some detail as follows. 
Mechanistic systems are isolated from their environment and only outside forces can change their structure [38]. This mechanistic worldview which is derived from classical physics of the nineteenth century leaves no room for any directiveness, order, or telos [57], and hence mechanistic systems have static teleology and assume one-way causality [57]. The principle of causality states that every effect is preceded, not followed, by a cause [47].

According to Porra [37], a mechanistic system does not have temporality; in other words, as soon as the purpose or goal of the system is determined by the initiator of the machine, the system stops changing, and "grows" by adding or changing parts to make its life longer. The system cannot evolve as a living system does [37]. Such systems are based on formal rules and can only operate with their hierarchy of rules no matter what the conditions and will ultimately fail when new environmental conditions emerge [31, 37, 38].

The organic worldview is introduced in response to insufficiencies in the mechanistic view [57] by adding the notion of feedback and control to the formal rule-based structures of mechanistic systems. Organic systems include an implicit assumption of progressive evolution [37]. The evolution of organic systems "is gradual, discontinuous unfolding of events by incremental adaptation to its immediate environment" [37:44]. According to Porra [37], an organic system may survive longer than a mechanistic system by making local corrections to its behaviours during dynamic times. But this paradigm cannot capture the nature of turbulent change or punctuation that happens in the context of organization.

To cope with this limitation, Porra [37] introduces so-called colonial systems. These are based on mobile animal colonies. Borrowing terms from the biological evolution field, a colony can be defined as [37:39] "a voluntary collection of individuals with the shared characteristics of a common evolutionary social history (phylogeny), common methods for realizing stability and radical change (species-level evolution), and a common local context". Porra [37] builds colonial systems as an alternative to the mechanistic and organic system perspective. Colonial systems see an organization as a complex adaptive system, not only a collection of individuals working alone but also interacting - collaborating and competing - at different levels [7]. In responding to the changes in the environment, members of the colonial systems co-evolve. Coevolution is a process where changes in an element depend (to varying degrees) on changes in other linked elements and will cause change in yet other ones [7]. Hence, as a result, the members of the system will have a shared evolutionary history [38].

GST in its various forms has been used in different areas of IS research [21]. Kendall and Kendall [23] point out that IS development methods, such as lifecycle concept or work breakdown structure, can be traced back to GST as underlying principles. Structured IS development methodologies are built upon the principles of mechanistic systems. Machines are used as the metaphor of this methodology [23]. Multiview methodology defines an IS as a social process using the principles of colonial systems to some extent. Kendall and Kendall [23] use society as a metaphor for this methodology. Soft-system methodology introduced by Checkland [8] also uses GST as underlying principles. In addition, Porra et al. [38] used GST with three metaphors, i.e. mechanistic, organic, and colonial systems, to construct the history of Texaco's corporate information technology function. 


\section{Institutional Theory}

The development of Institutional Theory can be traced back to its early development in economics, political science, and sociology [43]. This theory sees institutions as multifaceted, durable social structures made up of symbolic elements, social activities, and material resources. Institutions, however, are not just constraint structures but also simultaneously empower and control [20]. According to Scott [43:48], "institutions are comprised of regulative, normative and cultural-cognitive elements that, together with associated activities and resources, provide stability and meaning to social life". Scott [43] refers to regulative, normative and cultural-cognitive elements as the three elements or pillars of institutions.

The regulative conception assumes that institutions constrain and regularize behaviours by setting up rules and systems of rules [43]. Rules or systems of rules are symbolic systems and one of the carriers in the institutionalization process. According to Gil-Garcia and Martinez-Moyano [13], in an institution, systems of rules can be designed primarily as behaviour-constraining mechanisms and can be primarily thought of as a solution-guiding mechanism.

The emphasis of the normative view is that normative systems (i.e. values and norms) provide a prescriptive, evaluative, and obligatory dimension of social life [43]. Normative systems are seen as carriers in the institutionalization process. Here, values are defined as "the conceptions of the preferred or the desirable, together with the construction of standards to which existing structures or behaviour can be compared and assessed" [43:54], whereas norms "specify how things should be done" [43:54-55].

The third conception of institutions stresses the centrality of cultural-cognitive elements of institutions. This conception assumes that "internal" cognitive processes are shaped by an "external" cultural framework [43]. According to Douglas [10] - as cited in [43] - cultural categories should be treated as "the cognitive containers in which social interests are defined and classified, argued, negotiated, and fought out".

Although institutions function to provide stability and order, they undergo change that is both incremental and revolutionary [43]. In this sense, institutions are seen not only as a "property" or state of an existing social order, but also as a "process", including the processes of institutionalization and deinstitutionalization. Generally, institutionalization may be defined as "the process through which a social order or pattern becomes accepted as a social 'fact'" [3:236], whereas deinstitutionalization is "the process by which the legitimacy of an established or institutionalized organizational practice erodes or discontinues" [33:564]. For example, when information technology is adopted by an organization, the information technology development and organizational change involve the continuing institutionalization of information technology intertwined with the deinstitutionalization of the dominant organizational form [3].

According to Scott [42], institutionalization can be considered as a process of creating reality [6] or as a process of instilling value [45]. As a process of creating reality, Berger and Luckmann [6:54] - as cited in [42] - argue that, "Institutionalization occurs whenever there is a reciprocal typification of habitual actions by types of 
actors". Both actions and actors are typified: certain forms of actions come to be associated with certain classes of actors. As a process of instilling value, institutionalization is the process "to infuse with value beyond technical requirement of the task at hand" [45:17] - cited in [42]. Before value is instilled in an organization, it merely has instrumental utility as a mechanical and disposable tool [42].

External environment is seen as influential for organizations. Institutional Theory views organizations not as passive entities that are controlled by the demand of their environments but as active players capable of responding strategically and innovatively to environmental pressure [35]. According to Selznick [45] - cited in [3] - we cannot explain what is happening in organizations by considering only the "rational" actions of their members; indeed we should take into account "irrationalities" stemming from the context of the organization as well as from cultural systems embedded in organizations. Thus, organizations are subject to pressure to be isomorphic with the external environment through various mechanisms. There are three mechanisms of institutional isomorphic changes: coercive, mimetic, and normative [9, 42].

Coercive isomorphism stems from political influence and the problem of legitimacy and is a result of pressure exerted on organizations by other organizations upon which they are dependent, such as resource-dominant organizations, regulatory bodies, and parent corporations $[9,51]$. Normative isomorphism is associated with professionalization. In relational channels among members of a network, norms that are widely adopted by other organizations will influence organizational behaviour [9]. When organizations have direct and frequent communication with each other, they are more likely to think alike or behave similarly [51]. Mimetic isomorphism is a response to uncertainty. Uncertainty may emerge when organizational technologies are poorly understood, when goals are ambiguous, or when environments change [9]. In this case, over time, an organization may change to become more like other organizations in terms of its environment.

Scott [43] points out that institutional carriers are important in terms of the ways in which institutions change. He classifies carriers into four types: symbolic systems, relational systems, routines, and artefacts. Each institutional element has its own dominant carriers. For example, the carriers of the regulative element of institutions are rules, power systems, and standard operating procedures; values, authority systems, and roles are the carriers of the normative element; the carriers of the culturalcognitive element include typifications and identities.

Institutional Theory has been used as a lens in different areas of IS research. Most of the researchers using this theory believe that IT itself is an insufficient predictor of IT impact on organization performance improvement [e.g., 3, 4, 34, 35, 48, 51]. Avgerou (2004:234) suggests that, "IT innovation itself is a process of combining technicalrational and social forces, neither driving, nor subsumed in the forces of organizational change, but interacting with them". Orlikowski and Barley [35] suggest that IS scholars should take into account the institutional context where IS is developed and implemented. In addition, Institutional Theory is also used to portray the relationship between actors and to explain isomorphic mechanisms between the actors occurs during the IT implementation [e.g., 13, 19, 24, 51, 52]. 


\section{Explaining e-Government Implementation Using GST and Institutional Theory: An Analytical Framework}

Implementation of IS, in which e-Government is a specific instance of its application, could be approached from various ways. Myers [32] argues that generally, there are two mainstreams in IS literature when researching IS implementation: factor research and process research. Factor research or variance research [25, 40] tries to identify possible determinants of IS implementation success. This research speculates about the processes connecting antecedents with outcomes [40]. Unlike variance research, process research focuses on the development of IS projects. The focus of the research includes the relationship between the designers and the users of an IS, and the impact of the systems on the organization [32]. Process research seeks to explain how change emerges, develops, and diminishes over time [40].

Yet, from another stance, Keil [22] - as cited in [32] - suggests three models of IS implementation based on the nature of causality as a basis. The three models are: (a) implementation as technology acceptance; (b) implementation as organizational change; and (c) implementation as organizational problem solving involving mutual adaptation. The first two models assume that the design activities will produce the change smoothly, and the design system remains stable. Here, IS change can be considered as linear and cumulative in nature and involve either technical or social dimension [28]. The third model include the intertwined relationship between technical and social aspects of IS implementation. As Lyytinen and Newman [28] argue, the IS change should be seen as complex, multi-level, and punctuated change that involve both technical and social changes.

Inspired by the idea from GST by identifying isomorphic conceptions both in GST and Institutional Theory, the paper proposes an analytical framework that consists of three scenarios as follow.

\subsection{Scenario 1: Mechanistic Systems, Coercive, Techno-Centric, Accepters}

When an organization is considered as mechanistic systems, for example by assuming that the organization has static teleology, formal and unchanging rules, and is singularly purposeful (see Table 1), e-Government implementation may follow teleology model as pointed out by Van de Ven and Poole [55] ${ }^{1}$. Goal enactment is the generating force of the teleology model [55] which is also found in the conception of the mechanistic systems [37]. The teleology model consists of a cycle of goal formulation, implementation, evaluation, and modification of goals based on what was learned by the organization. Further, Van de Ven and Poole [55] argue that this sequence emerges through the purposeful social construction among individuals within the organization. Such conceptions can be found in the mechanistic paradigm [37, 38].

\footnotetext{
${ }^{1}$ Based on an extensive literature review across disciplines (200,000 titles, 2,000 abstracts, 200 articles), Van de Ven and Poole [54] identify four main organizational change models, i.e. teleology, life-cycle, evolution, and dialectic models. Each model has its own motors and assumptions.
} 
Table 1. Theoretical framework of analysis

\begin{tabular}{|c|c|c|c|c|}
\hline & Scenario 1 & Scenario 2 & Scenario 3 & Reference \\
\hline Departing worldview & Mechanistic systems & Organic systems & Colonial systems & $\begin{array}{l}31,37 \\
38,57]\end{array}$ \\
\hline Control & $\begin{array}{l}\text { Unchanging } \\
\text { Built-in }\end{array}$ & $\begin{array}{l}\text { Adapting through } \\
\text { feedback from } \\
\text { the environment }\end{array}$ & $\begin{array}{l}\text { Feedback and feed- } \\
\text { forward }\end{array}$ & {$[31,38]$} \\
\hline Change & Constancy of essence & $\begin{array}{l}\text { Linear adaptive } \\
\text { change }\end{array}$ & $\begin{array}{l}\text { Punctuated equilib- } \\
\text { rium }\end{array}$ & {$[28,37]$} \\
\hline $\begin{array}{l}\text { Institutional concep- } \\
\text { tions }\end{array}$ & Regulative & Normative & Cultural-cognitive & [43] \\
\hline Basis of legitimacy & Legally enforced & Morally governed & $\begin{array}{l}\text { Culturally support- } \\
\text { ed }\end{array}$ & [43] \\
\hline $\begin{array}{l}\text { Isomorphic mecha- } \\
\text { nism }\end{array}$ & Coercive & Normative & Mimetic & {$[9,43]$} \\
\hline Institutional carriers & $\begin{array}{l}\text { Rules } \\
\text { Power systems } \\
\text { Standard operating } \\
\text { procedures } \\
\end{array}$ & $\begin{array}{l}\text { Values } \\
\text { Authority systems } \\
\text { Roles }\end{array}$ & $\begin{array}{l}\text { Typifications } \\
\text { Identities }\end{array}$ & [43] \\
\hline $\begin{array}{l}\text { Implementation mod- } \\
\text { el }\end{array}$ & Teleology & $\begin{array}{l}\text { Life-cycle } \\
\text { Evolution }\end{array}$ & Dialectic & [55] \\
\hline Implementation focus & Techno-centric & $\begin{array}{l}\text { Government- } \\
\text { centric/ } \\
\text { Organization- } \\
\text { centric } \\
\end{array}$ & $\begin{array}{l}\text { Community- } \\
\text { centric/ } \\
\text { People-centric }\end{array}$ & {$[22,41]$} \\
\hline $\begin{array}{l}\text { Implementation per- } \\
\text { spective }\end{array}$ & $\begin{array}{l}\text { Technology ac- } \\
\text { ceptance }\end{array}$ & $\begin{array}{l}\text { Organizational } \\
\text { change }\end{array}$ & $\begin{array}{l}\text { Organizational } \\
\text { problem solving } \\
\text { involving mutual } \\
\text { adaptation }\end{array}$ & {$[22]$} \\
\hline $\begin{array}{l}\text { Institutional adoption } \\
\text { pattern }\end{array}$ & Accepters & Improvers & Transformers & [19] \\
\hline Institutional impact & Automated & Improved & Transformed & $\begin{array}{l}{[15,19,} \\
41]\end{array}$ \\
\hline
\end{tabular}

In the context of e-Government implementation, the teleology model is probably adopted in the beginning stage of e-Government implementation where technological determinism dominates the assumptions. In other words, the implementation is techno-centric [41], which mostly are the cases in developing countries that generally are lagging in e-Government implementation when compared to their counterparts in developed countries [54]. In the beginning stage, as well, most local governments implement e-Government initiatives to response to national government regulation or programs. Technical assistance and funding may be provided by the national government to foster the e-Government implementation in lower levels. Here, technology acceptance may be used as an indicator of successful implementation [22].

The mechanistic systems are formal rule-based [37] which are similar with the conception of regulative element of institutions, which is legally enforced [43]. The centralized power and control in the mechanistic systems [37] also found in the regulative element of institution that position power systems as one of the institutional carriers [43]. In this situation, from the perspective of Institutional Theory, coercive pressure from higher authority (i.e., the national government) may be influential. When the incentive is put as the main motor behind the process of institutionalization, eGovernment implementation may only be manifested as automation of the government 
business process [41]. Using Hjort-Madsen's [19] terminology, this local government could be considered as accepters in which the e-Government implementation is mainly to comply with the regulation from an upper authority. As an example, implementing teleconference technology to facilitate meeting between various levels of government agencies without any organizational changes may follow this scenario.

\subsection{Scenario 2: Organic Systems, Normative, Organization-Centric, Improvers}

Further, when e-Government as a system is perceived as an organic system in which the government seeks balance with the environment by adaptation, implementation model adopted may be life-cycle or evolution model [55]. In Porra's terminology [38], this is an adaptive process with fixed arrangement. Van de Ven and Poole [55] consider life-cycle implementation model as organic growth. This model assumes that the change process progresses through a necessary sequence of stage linearly. Meanwhile, the evolution model assumes that implementation consists of a repetitive sequence of variation, selection, and retention events among members of an organization [55]. The impact caused by the implementation process using these assumptions is incrementally progressive.

Using interpretation from Institutional Theory, when adaptation is carried out through feedback from the environment [43], normative pressures from other organizations, or in the context of e-Government implementation, from other local government may be very determining. This adaptation mechanism is similar with the organic paradigm that adds feedback and control, in addition to formal rule-based structures of the mechanistic systems [37]. In this stage, communication and contact among local governments intensifies. This process most probably adopted not in the beginning stage of e-Government implementation, but in a later stage when some e-Government systems have been put in place as foundations. In this stage of implementation, local governments may be considered as improvers [19]. They do not merely automate the business processes, but they also improve them to some extent. In this sense, implementation may be considered as organizational change [22]. We may coin this implementation as organization-centric or government-centric approach. Implementation of ERP-like package to improve the decision making and controlling process in a local government is an example of e-Government that probably follows this scenario.

\subsection{Scenario 3: Colonial Systems, Mimetic, Community-Centric, Transformers}

Lastly, when assumptions in colonial systems are used as points of departure, eGovernment implementation process may follow a different path. Colonial systems assume the existence of feedback and feedforward control between an organization and its environment. Over time, changes consist not only of stasis but also punctuations [38]. In this context, dialectic model described by Van de Ven and Poole [55] may accommodate the process. Dialectic models assume that the emergence of thesis and antithesis will create a conflict as a pre-process to produce a synthesis. In the dictionary of Institutional Theory, this conflict may produce confusion. This confused situation should be resolved by developing common beliefs that produce a shared understanding. This shared understanding is similar with the conception of shared evolutionary history and shared local context in colonial systems paradigm [38]. 
By integrating the two theories, we may postulate that colonial systems are built on cultural-cognitive conception of organizations; an organization is seen not only from technical aspect (as in mechanistic systems) or merely as social construction (as in organic systems), but from the understanding that social and technical aspects are intertwined, and the resulted changes are not only linear progression but also punctuations. In this context, mimetic pressures may dominate over coercive and normative pressures, since the role of culture building is very important [43]. Using Keil's [22] conceptions, this implementation may be considered as organizational problem solving involving mutual adaptation. Here, external environment gains a more substantial influence through a more intensive interaction and communication.

e-Government implementation that adopts the colonial systems and culturalcognitive conceptions may generate more radical changes. e-Government will not only automate or improve the business process, but goes beyond by transforming the local government. The governments are transformed, and hence they become not only accepters or improvers, but transformers [19]. In this stage, the government implementation is community-centric [41] or people-centric [53], beyond techno-centric and government-centric. In the context of e-Government, the government treats "citizen as a partner" ([14] - cited in [41]) or e-Government is considered as "transferring power to the people" ([26] - cited in [41]).

e-Government initiative that follows this implementation scenario may include establishment of one-stop services in various levels of government involving a variety of government agencies to improve the public service quality and transparency. In many cases, the implementation process is not straightforward, but is going through a rather long process involving a dialogue, and in some extent a political conflict, between various government agencies that worry about losing their power [12]. At the end, the process will transform government business processes that very much put the public service quality and transparency improvement at the highest priority.

\section{Concluding Remarks}

GST and Institutional Theory have been briefly presented in this paper. An analytical framework to explain e-Government implementation that is built upon the two theories has also been proposed. The main contribution of this paper is the introduction of three scenarios of e-Government implementation. Each of these scenarios in the analytical framework is with different departing worldview, isomorphic mechanism, implementation model, and possible impacts.

One possible approach would be to view these scenarios as adjustable analytical tools. In practice, these three scenarios most likely are not mutually exclusive, but they are interdependent and intersect in some extent, though a scenario may be predominant over the other two. This integration that preserves the distinction of each theory yields a richer theoretical framework that can be used as lenses to explain eGovernment implementation. However, to get a better understanding of the process of e-Government implementation over time, the framework should not be used mechanistically as a simple checklist.

Although the scenarios are theoretically supported, they need to be empirically examined. Possible expected result from the empirical studies is new understanding to evolution of the e-Government initiatives over a certain period of time. For instance, 
some e-Government implementations may have evolved organically or colonially and others, especially in the context of developing countries, may simply have been mechanistic. If these scenarios gain empirical support, then we can conclude that the departing worldview used in the process of e-Government implementation will partake in giving explanation to the e-Government success or failure. But, we should note here that definition of failure or success is dependent on the intended strategic purpose in the outset for a certain initiative [2]. A clear statement of the intended strategic purpose in the outset of each e-Government implementation then is very crucial in determining a scenario that may fit best. For example, in some cases [31], mechanistic systems are more preferable than organic and colonial systems. This new understanding, then, can be utilized as a basis to increase the success rate and to maximize the benefits of the e-Government implementation, especially in the developing countries which experience most e-Government implementation failures as reported by Heeks [16] and others, without closing the possibilities of applying the analytical framework in the context of developed countries.

\section{References}

1. Andersen, K.V., Henriksen, H.Z.: E-government maturity models: Extension of the Layne and Lee model. Government Information Quarterly 23, 236-248 (2006)

2. Aral, S., Weill, P.: IT assets, organizational capabilities, and firm performance: how resource allocations and organizational differences explain performance variation. Organization Science 18(5), 763-780 (2007)

3. Avgerou, C.: IT and organizational change: an institutionalist perspective. Information Technology and People 13(4), 234-262 (2000)

4. Baptista, J.: Institutionalisation as a process of interplay between technology and its organisational context of use. Journal of Information Technology 24(4), 305-320 (2009)

5. Basu, S.: E-government and developing countries: an overview. International Review of Law Computers and Technology 18(1), 109-132 (2004)

6. Berger, P.L., Luckmann, T.: The Social Construction of Reality. Doubleday, New York (1967)

7. Bitar, J.: Towards an Understanding of Elusive Organizational Phenomena: Organizations as Complex Adaptive Systems. HEC Montréal (2006)

8. Checkland, P.: Systems Thinking, Systems Practice. John Wiley \& Sons, Chichester (1999)

9. DiMaggio, P.J., Powell, W.W.: The iron cage revisited: Institutional isomorphism and collective rationality in organizational fields. American Sociological Review 48(2), 147-160 (1983)

10. Douglas, M.: The effects of modernization on religious change. Daedalus Winter, 1-19 (1982)

11. Duncan, D.M., Miller's, J.G.: Living Systems Theory: issues for management thought and practice. Academy of Management Journal 15(4), 513-523 (1972)

12. Furuholt, B., Wahid, F.: e-Government challenges and the role of political leadership in Indonesia: the case of Sragen. In: Proceedings of the 41st Hawaii International Conference on System Sciences, HICSS (2008)

13. Gil-Garcia, J.R., Martinez-Moyano, I.J.: Understanding the evolution of e-government: The influence of systems of rules on public sector dynamics. Government Information Quarterly 24(2), 266-290 (2007) 
14. Hague, B.N., Loader, B.D.: Digital democracy: an introduction. In: Hague, B.N., Loader, B.D. (eds.) Digital Democracy: Discourse and Decision-Making in the Information Age, pp. 1-22. Routledge, London (1999)

15. Heeks, R.: E-government in Africa: promise and practice. Information Polity 7, 97-114 (2002)

16. Heeks, R.: Most e-government-for-development projects fail: how can risks be reduced? iGovernment Working Paper Series, (14) (2003)

17. Heeks, R., Bailur, S.: Analyzing e-government research: perspectives, philosophies, theories, methods, and practice. Government Information Quarterly 24, 243-265 (2007)

18. Heeks, R., Stanforth, C.: Understanding e-Government project trajectories from an ac-tornetwork perspective. European Journal of Information Systems 16, 165-177 (2007)

19. Hjort-Madsen, K.: Institutional patterns of enterprise architecture adoption in government. Transforming Government: People, Process, and Policy 1(4), 333-349 (2007)

20. Jepperson, R.L.: Institutions, institutional effects, and institutionalism. In: Powell, W.W., Di Maggio, P.J. (eds.) The New Institutionalism in Organizational Analysis. The University of Chicago Press, Chicago (1991)

21. Kanungo, S., Jain, V.: General Systems Theory: a guiding framework for IS research. In: Proceedings of Americas Conference on Information Systems, Fort Collins, Colorado (2007)

22. Keil, M.: Managing MIS implementation: identifying and removing barriers to use. Unpublished PhD Thesis. Harvard University (1991)

23. Kendall, J.E., Kendall, K.E.: Metaphors and methodologies: living beyond the systems machine. MIS Quarterly 17(2), 149-171 (1993)

24. Kim, S., Kim, H.J., Lee, H.: An institutional analysis of an e-government system for anticorruption: the case of OPEN. Government Information Quarterly 26(1), 42-50 (2009)

25. Langley, A.: Strategies for theorizing from process data. Academy of Management Review 24(4), 691-710 (1999)

26. Lawson, G.: NetState. Demos, London (1998)

27. Layne, K., Lee, J.: Developing fully functional e-government: a four stage model. Government Information Quarterly 18(2), 122-136 (2001)

28. Lyytinen, K., Newman, M.: Explaining information systems change: a punctuated sociotechnical change model. European Journal of Information Systems 17, 589-613 (2008)

29. Maumbe, B.M., Owei, V., Alexander, H.: Questioning the pace and pathway of egovernment development in Africa: A case study of South Africa's Cape Gateway project. Government Information Quarterly 25(4), 757-777 (2008)

30. Moon, M.J.: The evolution of e-government among municipalities: rhetoric or reality? Public Administration Review 62, 424-433 (2002)

31. Morgan, G.: Images of Organization. Sage Publication, California (1996)

32. Myers, M.D.: Dialectical hermeneutics: a theoretical framework for the implementation of information systems. Information Systems Journal 5, 51-70 (1994)

33. Oliver, C.: The antecedents of deinstitutionalization. Organization Studies 13(4), 563-588 (1992)

34. Orlikowski, W., Robey, D.: Information technology and the structuring of organiza-tions. Information Systems Research 2(2), 143-169 (1991)

35. Orlikowski, W.J., Barley, S.R.: Technology and institutions: what can research on information technology and research on organizations learn from each other? MIS Quarterly 25(2), 145-166 (2001)

36. Pan, G., et al.: Escalation and de-escalation of commitment: a commitment transformation analysis of an e-government project. Information Systems Journal 16, 3-21 (2006) 
37. Porra, J.: Colonial Systems. Information Systems Research 10(1), 38-69 (1999)

38. Porra, J., Hirschiem, R., Parks, M.S.: The history of Texaco's corporate information technology function: a general systems theoretical interpretation. MIS Quarterly 29(4), 721-746 (2005)

39. Reddick, C.G.: A two-stage model of e-government growth: Theories and empirical evidence for U.S. cities. Government Information Quarterly 21(1), 51-64 (2004)

40. Robey, D., Ross, J.W., Boudreau, M.-C.: Learning to implement enterprise systems: an exploratory study of the dialectics of change. Journal of Management Information Systems 19(1), 17-46 (2002)

41. Sahraoui, S.: E-inclusion as a further stage of e-government? Transforming Government: People, Process and Policy 1(1), 44-58 (2007)

42. Scott, W.R.: The adolescence of Institutional Theory. Administrative Science Quarterly 32(4), 493-511 (1987)

43. Scott, W.R.: Institutions and Organizations. Sage, Thousand Oaks (2008)

44. Sein, M.K.: E-government in developing countries: linking G to $\mathrm{C}$ through I. In: Proceedings of the 1st International Conference on e-Government and e-Governance (ICEGOV 2009), Ankara, Turkey (2009)

45. Selznick, P.: Leadership in Administration. Harper and Row, New York (1957)

46. Siau, K., Long, Y.: Synthesizing e-government stage models - a meta-synthesis based on meta-ethnography approach. Industrial Management \& Data Systems 105(4), 443-458 (2005)

47. Skyttner, L.: General Systems Theory: Problems, Perspectives, Practice. World Scientific Publishing, Singapore (2005)

48. Soh, C., Sia, S.K.: An institutional perspective on sources of ERP package-organisation misalignments. The Journal of Strategic Information Systems 13(4), 375-397 (2004)

49. Stanforth, C.: Using Actor-Network Theory to analyze e-government implementation in developing countries. Information Technologies and International Development 3(3), 3560 (2006)

50. Stanforth, C.: Analysing e-government project failure: comparing factoral, systems and interpretive approaches. iGovernment Working Paper Series (20) (2010)

51. Teo, H.H., Wei, K.K., Benbasat, I.: Predicting intention to adopt interorganizational linkages: an institutional perspective. MIS Quarterly 27(1), 19-49 (2003)

52. Tingling, P.M., Parent, M.: Mimetic isomorphism and technology evaluation: Does imitation transcend judgment? Journal for the Association of Information Systems 3(5), 113 143 (2002)

53. United Nations: Global E-government Readiness Report 2005: From E-government to Einclusion. United Nations, New York (2005)

54. United Nations: United Nations e-Government Survey 2010: Leveraging E-government at a Time of Financial and Economic Crisis. United Nations, New York (2010)

55. Van de Ven, A.H., Poole, M.S.: Explaining development and change in organizations. Academy of Management Review 20(3), 510-540 (1995)

56. von Bertalanffy, L.: An outline of General System Theory. The British Journal for the Philosophy of Science 1(2), 134-165 (1950)

57. von Bertalanffy, L.: General System Theory: Foundations, Development, Applications. George Braziller, New York (1968)

58. Walsham, G., Sahay, S.: Research on information systems in developing countries: current landscape and future prospects. Information Technology for Development 12, 17-24 (2006)

59. Yildiz, M.: E-government research: reviewing the literature, limitations, and ways forward. Government Information Quarterly 24(3), 646-665 (2007) 